\section{Thymus vulgaris (red thyme) and Caryophyllus aromaticus (clove) essential oils to control spoilage microorganisms in pork under modified atmosphere}

Serena D'Amato,' Giovanni Mazzarrino,' Chiara Rossi, ${ }^{1}$ Annalisa Serio, ${ }^{1}$ Clemencia Chaves López, ${ }^{1}$

Gaetano Vitale Celano, ${ }^{2}$

Antonello Paparella ${ }^{1}$

'Faculty of Bioscience and Technology for Food, Agriculture and Environment, University of Teramo, Mosciano Sant'Angelo (TE); ${ }^{2}$ Department of Veterinary Medicine, University of Bari, Valenzano (BA), Italy

\section{Abstract}

In recent years, it has been confirmed that essential oils (EOs) exert antimicrobial activity as they are able to inhibit cell growth and inactivate microbial cells. The application of biopreservation strategies by means of EOs opens up interesting perspectives in the food industry, including meat production. The paper aims to evaluate the effects of Thymus vulgaris (red thyme) and Caryophyllus aromaticus (cloves) EOs on the development of the spoilage population of fresh pork packaged under modified atmosphere (MAP). In particular, the research was focused on Brochothrix thermosphacta, a specific spoilage microorganism of fresh meat packed in anaerobic conditions or under MAP. Amongst seven EOs, those that showed the highest antimicrobial activity on $5 \mathrm{~B}$. thermosphacta strains in vitro were: cloves [minimum inhibitory concentration (MIC) $0.6-2.5 \mathrm{mg} / \mathrm{mL}$ ], savory (MIC 2.5-5.0 $\mathrm{mg} / \mathrm{mL}$ ), and red thyme (MIC 2.5 to $20 \mathrm{mg} / \mathrm{mL}$ ). Red thyme and cloves EOs were selected for meat treatment, by increasing the dose at 20 and $40 \mathrm{mg} / \mathrm{mL}$ respectively, to take into account the matrix effect that can reduce EO availability. In spite of the minor efficacy observed in vitro, $40 \mathrm{mg} / \mathrm{mL}$ red thyme EO strongly limited the growth of $B$. thermosphac$t a$ in pork samples up to day 6 of storage [below 3.0 Log colony forming unit (CFU)/g, starting from 2.0 Log CFU/g at time 0], and exerted an antimicrobial effect also on the aerobic mesophilic count. Good results were obtained also with $20 \mathrm{mg} / \mathrm{mL}$ red thyme EO. The control of $B$. thermosphacta growth through EOs encourages research on alternative methods for extending the shelf life of fresh meat under MAP.

\section{Introduction}

Spoilage and pathogenic bacteria are causes of serious concern for the food industry because of fast deterioration of some products and diseases transmitted. Over the years, the food industry has implemented methods of preservation that include, for example, the use of synthetic substances, as well as physical or thermal treatments, and their combination (Gould, 2000). Spoilage microorganisms generate significant economic losses for producers as they decrease shelf life of products (in particular meat and meat products) by forming off-odours, colour changes, and unpleasant tastes (Ercolini et al., 2009). In addition, the emergence of bacteria that are resistant to the treatments used to contain their development in food is fostering research on alternative antimicrobial techniques (Rajkovic et al., 2009). Biopreservation strategies are a set of processes based on natural and sustainable technologies, aimed at the control of the multiplication of pathogenic or spoilage microorganisms in foods. In this perspective, scientific literature has recently showed an increasing interest in the application of vegetable extracts and essential oils (EOs). EOs are known and used since ancient times for their antioxidant and antimicrobial activity. They may find application in food preservation, shelf life extension, or can be employed as active compounds in packaging materials or in protein-based films ((Oussalah et al., 2004; Zivanovic et al., 2005; Zinaviadou et al., 2009; Tongnuanchan et al., 2012; Tongnuanchan and Benjakul, 2014)). Antimicrobial and antioxidant activity of EOs is due to their chemical composition that includes volatile bioactive compounds able to control pathogenic and spoilage microorganisms (Burt, 2004; Bakkali et al., 2008; Gutiérrez-Larraínzar et al., 2012; SolórzanoSantos and Miranda-Novales, 2012; Gyawali and Ibrahim, 2014).

Brochothrix thermosphacta, a Gram-positive and facultative anaerobic species, is an important spoilage organism in fresh pork stored under modified atmosphere packaging (MAP), together with Pseudomonas spp. and lactic acid bacteria. The products of its metabolism mainly cause off-flavours, discoloration, gas production, and a pungent cheesy smell (McClure $e t$ al., 1993; Nychas et al., 2008; Gribble and Brightwell, 2012; Casaburi et al., 2014).

The aim of the study was to evaluate the in vitro inhibitory activity of seven EOs (Caryophyllus aromaticus, Mentha piperita var. Mitcham, Origanum vulgare, Rosmarinus officinalis, Salvia officinalis, Satureja montana, Thymus vulgaris) against Brochothrix thermosphacta strains isolated from meat products. Moreover, two EOs (C. aromaticus and T. vulgaris) were selected and tested against $B$. ther-
Correspondence: Antonello Paparella, Faculty of Bioscience and Technology for Food, Agriculture and Environment, University of Teramo, via C.R. Lerici 1, 64023 Mosciano Sant'Angelo (TE), Italy. $\mathrm{Tel} / \mathrm{Fax}:+39.0861 .266944$.

E-mail: apaparella@unite.it

Acknowledgements: Giardino Officinale Propezzano (TE), and Zuccari srl, Trento, Italy.

Key words: Essential oil; Brochothrix thermosphacta; Pork; MAP.

Contributions: the authors contributed equally.

Conflict of interest: the authors declare no potential conflict of interest.

Received for publication: 29 January 2016 .

Revision received: 8 March 2016.

Accepted for publication: 6 April 2016.

This work is licensed under a Creative Commons Attribution-NonCommercial 4.0 International License (CC BY-NC 4.0).

(O) Copyright S. D'Amato et al., 2016

Licensee PAGEPress, Italy

Italian Journal of Food Safety 2016; 5:5785

doi:10.4081/ijfs.2016.5785

mosphacta and mesophilic aerobic bacteria (MAB) in fresh pork samples packed under modified atmosphere, to evaluate the possible impact on shelf life extension.

\section{Materials and Methods}

\section{Essential oils}

The EOs used for this study were purchased from two Italian companies: Giardino Officinale [Propezzano (TE), Italy] and Zuccari srl (Trento, Italy). Details on the seven E0s are shown in Table 1. EOs were diluted by using sterile phosphate buffered saline (PBS)

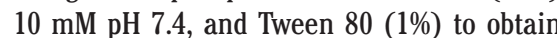
emulsions with an initial concentration of 40 $\mathrm{mg} / \mathrm{mL}(\mathrm{V} / \mathrm{N})$.

\section{Brochothrix thermosphacta strains}

Five strains of $B$. thermosphacta were employed to test the antimicrobial activity of the EOs listed above. Four strains were isolated from meats, and one type strain was purchased from the American Type Culture Collection (Teddington, UK; ATCC 11059). The strains were stored at $-80^{\circ} \mathrm{C}$ in Brain Heart Infusion (BHI; 0xoid Thermofisher, Basingstoke, UK) and glycerol (20\% V/V; Sigma Aldrich, St. Louis, M0, USA) to protect bacterial cells from low temperatures damage. Before each test, the bacterial strains were 
cultivated overnight at $30^{\circ} \mathrm{C}$ in BHI Agar (Oxoid Thermofisher), then a single colony of B. thermosphacta was inoculated into $1 \mathrm{~mL}$ of $\mathrm{BHI}$ broth, and incubated at $30^{\circ} \mathrm{C}$ for $18 \mathrm{~h}$. The cells obtained were centrifuged at $13,000 \mathrm{rpm}$ for $5 \mathrm{~min}$ (Eppendorf centrifuge 5415D; Hauppauge, NY, USA), and the pellet was washed three times with PBS $10 \mathrm{mM}, \mathrm{pH}$ 7.4. The inocula were standardised at about $10^{6}$ colony forming unit (CFU)/mL, by measuring the absorbance at $600 \mathrm{~nm}$ (UV-VIS, Jenway 6305 spectrophotometer; Bibby Scientific Ltd, Stone, UK), and were systematically verified by plate count, by using the selective medium Streptomycin Thallous Acetate Actidione (STAA; 0xoid Thermofisher), with readings after $24 \mathrm{~h}$ of incubation at $30^{\circ} \mathrm{C}$.

\section{Preparation of fresh pork samples}

The experiment was conducted on Italian fresh pork samples collected from Longissimus dorsi between the third vertebra and the tailbone. The muscular portions, previously cut into slices, were dissected into pieces with an average weight of $25 \mathrm{~g}$.

\section{Determination of minimal inhibito- ry concentration}

Seven EOs were used to determine the minimum inhibitory concentration (MIC), which is the lowest concentration required to inhibit the growth of the five strains of $B$. thermosphacta after $48 \mathrm{~h}$ of incubation at $30^{\circ} \mathrm{C}$. MIC was evaluated by applying the microdilution method (CLSI, 2011) on microtitre plates (Oxoid Thermofisher). In each plate a positive control, consisting of $100 \mu \mathrm{L}$ of inoculum and $100 \mu \mathrm{L}$ of BHI broth (Oxoid Thermofisher), was added to ascertain the vitality of the strain employed, and a negative control, consisting of $100 \mu \mathrm{L}$ of BHI broth, was used to ensure sterility of the culture medium.

\section{Fresh pork samples dipped in essential oils emulsions}

Each meat sample was dipped in E0s emulsions ( 20 and $40 \mathrm{mg} / \mathrm{mL}$ of cloves or red thyme, respectively) for $60 \mathrm{sec}$, and was left to dry in sterile Petri dishes under the flow of a microbiological cabinet for about $1 \mathrm{~h}$. Negative con- trols (non-treated with EOs) were also prepared. Dry samples were placed on polystyrene trays (Aerpack B5, 230×145×26 mm; Coopbox Group Spa, Reggio Emilia, Italy), packed under MAP $\left(70 \% 0,20 \% \mathrm{CO}_{2}, 10 \% \mathrm{~N}_{2}\right)$ in a heatsealed PET12/EVOH/PE50 top film (CXTop $64 \mu$ AntiFog; Coopbox Group Spa) and stored at $4^{\circ} \mathrm{C}$ for subsequent analysis. The amount of E0s employed (20 and $40 \mathrm{mg} / \mathrm{mL}$ ) refers to the emulsions applied exclusively on the surface of the pork treated; so, the actual amount of EOs referred to the weight of the samples is markedly lower than that applied by dipping.

\section{Microbiological analysis and deter- mination of Brochothrix thermo-}

\section{sphacta count}

Microbiological analyses were performed up to day 13 of storage at times T0, T2, T4, T6, T8, $\mathrm{T} 10$, and $\mathrm{T} 13$, to determine the count of MAB and $B$. thermosphacta in the treated samples. MAB were enumerated on Plate Count Agar, and $B$. thermosphacta on STAA medium (Oxoid Thermofisher), after incubation at $30^{\circ} \mathrm{C}$ for 48 h. Microbiological analyses were conducted for 13 days (three days after the expiry date recommended by the manufacturer of pork stored at same conditions in MAP) to detect the possible extension of product shelf life. The MAB count was carried out to obtain information useful to judge the samples deterioration and to assess the products shelf life.

\section{Sensory analysis}

The triangle test (ISO 4120:2004; ISO, 2004) has been administered to the panelists. This type of test is a procedure for determining whether a perceptible sensory difference or similarity exists between two products. For each taster three samples (coded anonymously), two of which identical and one different, were presented. The three samples were identified by random three digits code and were contemporarily and randomly presented to each judge in plastic dishes. Presentation was random to balance the test and to avoid the alone effect. Each taster was asked to identify the different sample. The taste tests were repeated twice in the same day. Pork samples were evaluated at three storage times (T0, T6,
T10) in order to detect differences in the judges' EOs perception.

Pork samples, treated with $4 \%$ emulsions of red thyme and cloves E0s, together with control samples, were subjected to sensory evaluation by a group of ten panelists of different age and sex. The samples were sectioned into cubes of about $2 \times 2 \times 2 \mathrm{~cm}$ and cooked through an electric oven (Air-0-Steam COMBI 6GN 1/1; Electrolux, Stockholm, Sweden) set to $140^{\circ} \mathrm{C}$. Pork cubes were cooked for $7 \mathrm{~min}$, reaching $70^{\circ} \mathrm{C}$ at the product core (temperature control was performed by a thermocouple Velp Scientific VTF digital thermoregulator; Velp, Usmate, Italy).

The aim of the triangle test was to verify the tasters' recognition of the samples treated with EOs compared to untreated ones. In addition, a comment section was included for the assessor's remark and the judges were asked to indicate the samples with the most intense aroma.

\section{Statistical analysis}

Analyses were run in triplicate. Microbiological counts were converted to Log $\mathrm{CFU} / \mathrm{g}$ and were subjected to analysis of variance (ANOVA) with a confidence interval of 95\%. Means and standard deviations were calculated. Differences among means were evaluated by Tukey test, with significance defined at $\mathrm{P}=0.05$.

\section{Results}

\section{Determination of in vitro antimi-} crobial activity of essential oils against Brochothrix thermosphacta

Minimal inhibitory concentration values were recorded after $48 \mathrm{~h}$ of incubation at $30^{\circ} \mathrm{C}$ and results are shown in Table 2. The EOs that showed the highest antimicrobial activity in vitro were, in order: cloves (MIC 0.6-10.0 $\mathrm{mg} / \mathrm{mL}$ ), savory (MIC $2.5-20.0 \mathrm{mg} / \mathrm{mL}$ ), and red thyme (MIC 2.5-20.0 $\mathrm{mg} / \mathrm{mL}$ ). Among the effective EOs, the most and the least effective (respectively clove and red thyme) were selected for further trials, and their

Table 1. Description of the seven essential oils studied: plant species, common name, distilled part, providing companies.

\begin{tabular}{lccc} 
Plant species & Common name & Distilled part & Company \\
Caryophyllus aromaticus & Cloves & Flower & ZU \\
Mentha piperita var. Mitcham & Peppermint & Leaf & GO \\
\hline Origanum vulgare & Oregano & Leaf & GO \\
Rosmarinus officinalis & Rosemary & Leaf & GO \\
\hline Salvia officinalis & Sage & Leaf & $\mathrm{GO}$ \\
Satureja montana & Winter savory & Flowered plant & $\mathrm{GO}$ \\
\hline Thymus vulgaris & Red thyme & Leaf & ZU \\
\hline
\end{tabular}

GO, Giardino Officinale [Propezzano (TE), Italy]; ZU, Zuccari srl (Trento, Italy). 
concentration was increased at 20 and 40 $\mathrm{mg} / \mathrm{mL}$ to consider the matrix effect that decreases the availability of bioactive compounds.

\section{Determination of Brochothrix ther-} mosphacta and mesophilic aerobic bacteria growth in pork samples treated with essential oils

Counts of $B$. thermosphacta in pork samples are shown in Figure 1. At T0, red thyme EO at both concentrations and $40 \mathrm{mg} / \mathrm{mL}$ of cloves E0 slightly reduced the count compared to the untreated control. During the storage (13 days at $4^{\circ} \mathrm{C}$ ), red thyme EO controlled the development of $B$. thermosphacta, at both concentrations of 20 and $40 \mathrm{mg} / \mathrm{mL}$. Instead, cloves EO was not able to reduce $B$. thermosphacta growth; still, in some sampling times (T2 and T4) cell growth seemed even encouraged. The $40 \mathrm{mg} / \mathrm{mL}$ concentration of red thyme EO was the most effective, as it exerted a bacteriostatic effect on Brochothrix during the first six days of storage, and kept the counts significantly lower $(\mathrm{P}<0.05)$ than control until the end of storage. In particular, at T2, 3.76 Log $\mathrm{CFU} / \mathrm{g}$ were detected for the untreated control, and 2.30 Log CFU/g for the samples treated with $40 \mathrm{mg} / \mathrm{mL}$ of red thyme EO $(\mathrm{P}<0.01)$; at $\mathrm{T} 6$, the count in $40 \mathrm{mg} / \mathrm{mL}$ of thyme EO treated samples was significantly $(\mathrm{P}<0.01)$ lower than the control (about $2.50 \mathrm{Log} \mathrm{CFU} / \mathrm{g}$ ). Until T13, the count values were closer, but still significantly different $(\mathrm{P}<0.01)$, with $6.86 \mathrm{Log} \mathrm{CFU} / \mathrm{g}$ for the untreated control and $6.17 \mathrm{Log} \mathrm{CFU} / \mathrm{g}$ for the sample treated with $40 \mathrm{mg} / \mathrm{mL}$ of red thyme EO. Thyme EO at concentration of 20 $\mathrm{mg} / \mathrm{mL}$ limited $B$. thermosphacta growth with respect to control only up to $\mathrm{T} 6$.

The results for the mesophilic aerobic bacteria are summarised in Figure 2. At T0, there was an immediate and significant $(\mathrm{P}<0.01)$ decrease of the aerobic mesophiles in the samples treated with the EOs of red thyme and cloves $(40 \mathrm{mg} / \mathrm{mL})$, with 3.08 and $3.30 \mathrm{Log}$ $\mathrm{CFU} / \mathrm{g}$ respectively, compared to the control (3.72 $\log \mathrm{CFU} / \mathrm{g}$ ). The bacteriostatic effect of the E0s was more evident at T2, when 20 and $40 \mathrm{mg} / \mathrm{mL}$ of thyme EO and $40 \mathrm{mg} / \mathrm{mL}$ of cloves E0s were significantly $(\mathrm{P}<0.01)$ effective in containing the growth. The growth reduction with respect to control was maintained until $\mathrm{T} 6$, when $40 \mathrm{mg} / \mathrm{mL}$ of red thyme EO had the best performance in reducing the count of about 1.6 Log CFU/g. The efficacy of cloves and red thyme E0 at the lower concentration was progressively reduced over time up to T13, when only 20 and $40 \mathrm{mg} / \mathrm{mL}$ red thyme EOs were still able $(\mathrm{P}<0.01)$ to control microbial growth (6.03 and 6.18 Log CFU/g, respectively, with $6.93 \mathrm{Log} \mathrm{CFU} / \mathrm{g}$ in the control).

\section{Sensory analysis}

In the triangle test (data not shown), the panelists recognised the different samples (treated with EOs) in the tasting evaluations $(\alpha=0.001)$. The questions, aimed at investigating the flavour perception in the meat sample, revealed that almost all the panelists identified the treated samples (with EOs) as more aromatic.

\section{Discussion}

In vitro assays revealed a greater effectiveness of cloves E0 than red thyme, while in situ, red thyme EO showed a higher ability to control the development of $B$. thermosphacta. This result is not surprising as in vitro the medium variables are rather contained, whereas in a complex system such as meat, substrate composition influences the availability of bioactive compounds and the interaction with the microorganism. Moreover, MIC data obtained

Table 2. Minimum inhibitory concentration values (expressed as $\mathrm{mg} / \mathrm{mL}$ ) of seven essential oils against five Brochotrix thermosphacta strains after $48 \mathrm{~h}$ of incubation at $30^{\circ} \mathrm{C}$.

\begin{tabular}{|c|c|c|c|c|c|}
\hline \multirow[t]{2}{*}{ Essential oils } & \multicolumn{5}{|c|}{ Brochothrix thermophacta strains } \\
\hline & ATCC 11059 & B1 & B2 & B3 & B4 \\
\hline Caryophillus aromaticus & 0.6 & 2.5 & 2.5 & 10.0 & 10.0 \\
\hline Mentha piperita Mitcham & 2.5 & ne & ne & ne & ne \\
\hline Origanum vulgare & 1.3 & 10.0 & 10.0 & ne & ne \\
\hline Rosmarinus officinalis & ne & ne & ne & ne & ne \\
\hline Salvia officinalis & ne & ne & ne & ne & ne \\
\hline Satureja montana & 5.0 & 5.0 & 2.5 & 20.0 & 20.0 \\
\hline Thymus vulgaris & 2.5 & ne & 20.0 & 10.0 & 10.0 \\
\hline
\end{tabular}

ne, not effective at the tested concentrations. Standard deviation was not reported, as the tests repetitions showed no variability.

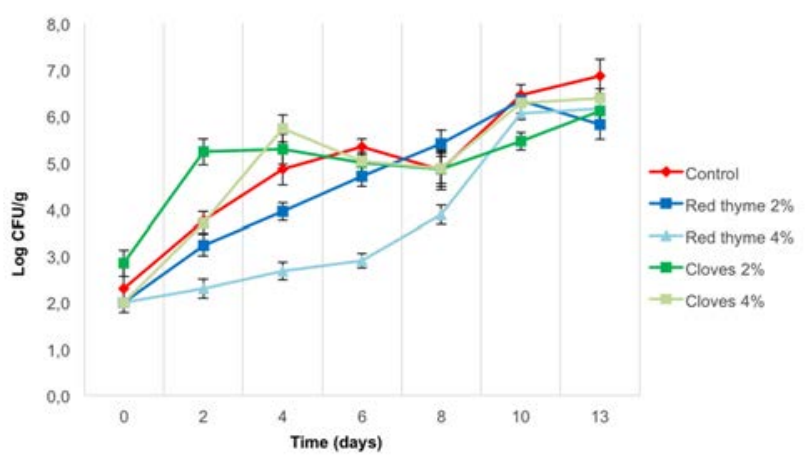

Figure 1. Counts of Brochothrix thermosphacta in pork samples under modified atmosphere during thirteen days of storage at $4^{\circ} \mathrm{C}$.

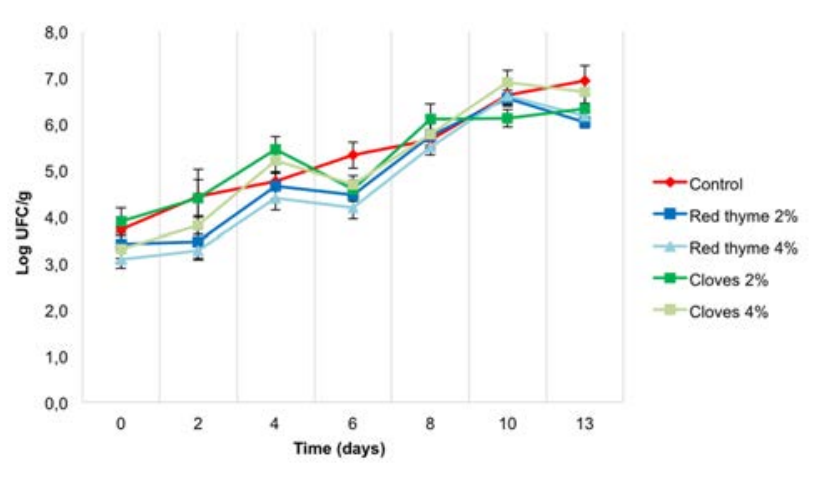

Figure 2. Counts of mesophilic aerobic bacteria in pork samples under modified atmosphere during thirteen days of storage at $4^{\circ} \mathrm{C}$. 
on specific strains do not necessarily correspond to the behaviour of the species.

Red thyme EO emulsion at $40 \mathrm{mg} / \mathrm{mL}$, applied on the surface of meat samples, was able to contain the growth of mesophilic aerobic and $B$. thermosphacta. This effect is not properly bactericidal but bacteriostatic because it was likely due to a Lag phase extension, as a cell response to the stress caused by phytocomplexes. The compounds that characterise red thyme E0 composition are borneol, carvacrol and thymol (Mazzarrino et al., 2015). They exert their antimicrobial activity against the cytoplasmic membrane, which is progressively damaged proportionally to the increase of employed E0 concentration (Serio et al., 2010); furthermore, these compounds disrupt the membrane potential, and produce a loss of ions, adenosine triphosphates (ATP) and small molecules until the cell death (Ultee et al., 2000; Di Pasqua et al., 2007; Cristiani et al., 2007). Cloves EO, mainly composed of eugenol, acts differently compared with red thyme oil because it causes a non-specific membrane permealisation and inhibits the action of certain enzymes such as histidine decarboxylase, amylase, protease and ATPase (Hemaiswarya and Doble, 2009). The great differences in the chemical composition of the two EOs used on meat samples might explain the different degree of $B$. thermosphacta containment during 13 days of storage at $4^{\circ} \mathrm{C}$.

\section{Conclusions}

In spite of its effectiveness, the amount of red thyme EO (MIC $40 \mathrm{mg} / \mathrm{mL}$ ) is quite high to be applied on the surface of fresh pork without affecting the sensory profile of the product. However, the association of red thyme EO with other natural preservatives, such as chitosan or other protein-based films, could open up new perspectives for the shelf life extension of meat. The containment of a spoilage bacterium like $B$. thermosphacta through the use of EOs encourages the research on alternative methods for extending the shelf life of fresh meat stored under MAP.

\section{References}

Bakkali F, Averbeck S, Averbeck D, Idaomar M, 2008. Biological effects of essential oils: a review. Food Chem Toxicol 46:446-75.
Burt S, 2004. Essential oils: their antibacterial properties and potential applications in food: a review. Int J Food Microbiol 94:22353.

Casaburi A, De Filippis F, Villani F, Ercolini D, 2014. Activities of strains of Brochothrix thermosphacta in vitro and in meat. Food Res Int 62:366-74.

CLSI, 2011. Performance standards for antimicrobial susceptibility testing: twenty-first informational supplement, M100-S21, Wayne, PA, USA

Cristiani M, D'Arrigo M, Mandalari G, Castelli F, Sarpietro MG, Micieli D, Venuti V, Bisignano G, Saija A, Trombetta D, 2007. Interaction of four monoterpenes contained in essential oils with model membranes: implications for their antibacterial activity. J Agr Food Chem 55:63-8.

Di Pasqua R, Betts G, Hoskins N, Edwards M, Ercolini D, Mauriello G, 2007. Membrane toxicity of antimicrobial coompounds from essential oils. J Agr Food Chem 55:486370.

Ercolini D, Russo F, Nasi A, Ferranti P, Villani F, 2009. Mesophilic and psychrotrophic bacteria from meat and their spoilage potential in vitro and in beef. Appl Environ Microb 75:1990-2001.

Gould GW, 2000. Preservation: past, present and future. Brit Med Bull 56:84-96.

Gribble A, Brightwell G, 2012. Spoilage characteristics of Brochothrix thermosphacta and campestris in chilled vacuum packaged lamb and their detection and identification by real time PCR. Meat Sci 94:3618.

Gutiérrez- Larraínzar M, Rúa J, Caro I, de Castro C, de Arriaga D, García-Armesto MR, del Valle P, 2012. Evaluation of antimicrobial and antioxidant activities of natural phenolic compounds against foodborne pathogens and spoilage bacteria. Food Control 26:555-63.

Gyawali R, Ibrahim SA, 2014. Natural products as antimicrobial agents. Food Control 46:412-29.

Hemaiswarya S, Doble M, 2009. Synergistic interaction of eugenol with antibiotics against Gram negative bacteria. Phytomedicine 16:997-1005.

ISO, 2004. Sensory analysis. Methodology. Triangle test. ISO Norm 4120:2004. International Standardization Organization ed., Geneva, Switzerland.

Mazzarrino G, Paparella A, Chaves-López C, Faberi A, Sergi M, Sigismondi C, Compagnone D, Serio A, 2015. Salmonella enterica and Listeria monocytogenes inactivation dynamics after treatment with selected essential oil. Food Control 50:794803.

McClure PJ, Baranyi J, Boogard E, Kelly TM, Roberts TA, 1993. A predictive model for the combined effect of $\mathrm{pH}$, sodium chloride and storage temperature on the growth of Brochothrix thermosphacta. Int J Food Microbiol 19:161-78.

Nychas GJE, Skandamis PN, Tassou CC, Koutsoumanis KP, 2008. Meat spoilage during distribution. Meat Sci 78:77-89.

Oussalah M, Caillet S, Salmieri S, Saucier L, Lacroix M, 2004. Antimicrobial and antioxidant effects of milk protein-based film containing essential oils for the preservation of whole beef muscle. J Agr Food Chem 52:5598-605.

Rajkovic A, Smigic N, Uyttendale M, Medi H, De Zutter L, Devlieghere F, 2009. Resistance of Listeria monocytogenes, Escherichia coli 0157:H7 and Campylobacter jejuni after exposure to repetitive cycles of mild bactericidal treatments. Food Microbiol 26:889-95.

Serio A, Chiarini M, Tettamanti E, Paparella A, 2010. Electronic paramagnetic resonance investigation of the activity of Origanum vulgare L. essential oil on Listeria monocytogenes membrane. Lett Appl Microbiol 51:149-57.

Solórzano-Santos F, Miranda-Novales MG, 2012. Essential oils from aromatic herbs as antimicrobial agents. Curr Opin Biotech 23:136-41.

Tongnuanchan P, Benjakul S, 2014. Essential oils: extraction. Bioactivities and their uses for food preservation. J Food Sci 79:1231-49.

Tongnuanchan P, Benjakul S, Prodpran T, 2012. Properties and antioxidant activity of fish skin gelatin film incorporated with citrus oil. Food Chem 134:1571-9.

Ultee A, Kets EP, Alberda M, Hoekstra FA, Smid EJ, 2000. Adaptation of the food-borne pathogen Bacillus cereus to carvacrol. Arch Microbiol 174:233-8.

Zinaviadou KG, Koutsoumanis KP, Biliaderis CG, 2009. Physico-chemical properties of whey protein isolate films containing oregano oil and their antimicrobial action against spoilage flora of fresh beef. Meat Sci 82:338-45.

Zivanovic S, Chi S, Draughon AF, 2005. Antimicrobial activity of chitosan films enriched with essential oils. J Food Sci 70:45-51. 